\title{
Religious Networks in Post-conflict Democratic Republic of the Congo: A Prognosis
}

\section{Ayo Whetho \& Ufo Okeke Uzodike*}

\section{Abstract}

The role of religion and religious networks in public life is gaining increasing attention in contemporary social science discourses against the backdrop of ascendant religiosity in many non-Western societies. In Africa, the reality of ascendant religiosity is exemplified by the phenomenal growth in the membership of the two leading religions - Christianity and Islam - and the increase in the number of other syncretic sects. Within this context, religious networks have emerged as important actors in civil society and as powerful forces for social mobilisation, albeit for both constructive and destructive ends. With reference to the Democratic Republic of the Congo (DRC), religious groups wield enormous influence in the public space as providers of social services in a polity that has been characterised by years of misrule, declining state capacity and protracted conflict. The conflict in the DRC has deepened the imperative for constructive engagement by faith-based groups

* Ayo Whetho is a doctoral candidate in Political Science, School of Politics, University of KwaZulu-Natal, South Africa.

Ufo Okeke Uzodike is an Associate Professor and Head, School of Politics, University of KwaZulu-Natal, South Africa. 
in the public domain, especially in facilitating the peacebuilding process. Against this background, this paper examines the roles of religious networks in the DRC's public sphere in the post-conflict epoch and prognosticates the future of the country.

\section{Introduction}

Those who neglect religion in their analyses of contemporary affairs do so at great peril (Berger 1999:18).

Berger's assertion is underscored by the realisation of the increasing socio-political role of religion in human affairs, or as Rubin (1994:20) puts it, its 'profound political influence in public life.'. In fact, religion features prominently in public life in relation to many social phenomena. For example, Wilson (1982:34) aptly notes that religion often serves to legitimise the purposes and procedures of society; sustain men in their struggle; justify wars; provide explanations for misfortunes; function as a platform for dispute resolution; and prescribe techniques with which people could undertake daily tasks or once-in-a-lifetime enterprises. Paradoxically, religion (and its role in society) has been a subject of intense debate over the years. For much of the twentieth century though, religion was ignored or marginalised in the analyses of social, economic, and political phenomena. This was due largely to the dominance of non-eschatological paradigms, which were influenced primarily by the Age of Enlightenment as well as the writings of philosophers. Haynes (1993:6) notes that 'the analysis of political behaviour for the greatest part of the twentieth century was dominated by the modernisation and political development paradigm, dependency/ underdevelopment, neo-Marxist and other radical perspectives'. Religion

1 It is instructive to note from the outset that religion plays different, contradictory roles in public life. In some instances, religion has been a force for bad, as exemplified by the culpability of religious actors in a number of conflicts around the world and the legitimation of violence through religious rhetoric. On the other hand, there is ample evidence, which suggests that religion also serves as a resource for peace. This is illustrated by the positive role of faith-based organisations in social service delivery and facilitating peacebuilding. That religion functions as a force for both good and bad depicts the socially ambivalent character of religion in public life. 


\section{Religious Networks in Post-conflict Democratic Republic of the Congo}

was considered as purely tenacious and atavistic. At best, religion was ignored; at worst, it was regarded as 'an opium' (à la Marx) and completely denounced.

The promise held forth by the dominant theories of liberalism, modernisation, and Marxism, spawned the prediction of the decline or demise of religion. Cox (1965:1) and Wallace (1966:264) had predicted that religion was to disappear and become consigned to history. In other words, the decline (and the possible extinction) of religion, in view of the inception of modernity, was expected. According to Rubin (1994:21), it was anticipated - in the West during the $18^{\text {th }}, 19^{\text {th }}$ and (early part of the) $20^{\text {th }}$ centuries that 'modern ideas, such as science, technology, secularism, and humanism, would overcome the religious concepts that dominated premodern society' Lubbe (2002:237) notes that this expectation was informed by the conviction that 'modernity goes hand in hand with a decline in religion'. The advent of the Cold War reinforced the fervour concerning the atrophy of religion as ideologies such as capitalism, socialism/communism, imperialism, and nationalism gained ascendance in the analyses of issues. Again, religion was viewed as 'irrational and premodern' (Weigel 1991:27; Reychler 1997). In the defunct Communist bloc, religion was officially stigmatised and repressed. In the West, it was regarded as a remnant of tradition. Religion was simply depicted as 'epiphenomena' (Haynes, 1993:6). The tendentious treatment of religion in both academic circles and in the public domain promoted secularisation. The futuristic resurgence of religion was not anticipated. However, in deference to Crawford's (2002:204) opinion that religion has a way of revitalising itself, the resurgence of religion (in the form of intensifying religiosity) has been witnessed in Africa and Eastern Europe, thereby stultifying the central propositions (associated predictions) of Marxism, modernisation, and development paradigms vis-à-vis its future.

The 'crisis of modernity', according to Lubbe (2002:240), is one of the three factors that account for the renaissance of religion. The inability of modernity (and secular philosophies) to furnish convincing explanations regarding the origin and destiny of human life has made religion attractive. Hence, Rubin (1994:23) submits that 'the secret of the influence of religion 
in contemporary politics is that the modernization process, rather than causing religion to weaken and disappear, often makes its public role stronger and a more necessary part of the process of state-building or revolutionary transformation'. Furthermore, the contradictions of globalisation (such as the mass movement of refugees and economic immigrants across national boundaries, and the weakening of state boundaries) have resulted in the loss of identity and national self-confidence in many societies. The search for identity has led many to religion. In addition, 'political uncertainty and financial risks' associated with the globalised environment induce volatility and instability that necessitate considerable adjustment. Within this milieu, religion is seen as a stabilising factor since it 'provides humanity with a sense of direction and destiny' (Lubbe 2002:240).

The above submissions find practical expression in many societies in the Third World, particularly in Africa, such that 'the political importance of religion reverberates with special strength in these societies' (Rubin 1994:22). For example, the Commission for Africa (CFA) (2005:120) notes the astounding increase in religiosity in Africa, which is underpinned by certain causalities. The CFA argues that nationalism in Africa is exhausted and that its place has been overtaken by religion. Bunting (2005) adds that 'politicians and state structures have lost almost all credibility or legitimacy'. Consequently, religion has emerged as a strong socio-political factor in galvanising people such that it cannot - and should not - be ignored in the analyses of contemporary issues - in Africa and elsewhere. Indeed, religion is assuming greater importance in many countries irrespective of their level of economic development (Thomas 2000:817). Given this context therefore, it is apposite to examine the underlying dynamics of intensifying religiosity currently underway in Africa. One of such dynamics is the increasing importance of religion in the public domain (especially in countries that have a weak state apparatus) such that faith-based actors are often co-opted into crucial local and national decision-making structures and processes in that they are a key constituency in civil society. In this paper, we use the DRC to illustrate this fact. But first, it is appropriate to highlight briefly religious 
affiliation in the DRC with a view to depicting the influence of faith-based networks in the country.

\section{DRC: Religious Demography}

In Africa, nowhere is the strategic importance of the religious constituency more apparent than in the DRC, where faith-based networks wield enormous influence over large sections of the national population. The country's religious demography attests to this: the DRC has a huge Christian population (put at $80 \%$ ), predominantly Roman Catholic. Approximately $50 \%$ of the DRC's population is Roman Catholic, 20\% is Protestant, $10 \%$ is Kimbanguist, $10 \%$ is Muslim while the remaining $10 \%$ comprises other religious organisations, syncretic sects and traditional religions. ${ }^{2}$ It is stated elsewhere that $16.5 \%$ of the population is Kimbanguist and that Islam 'counts only a small number of adherents in DR Congo, perhaps $1 \%$ of the population and principally clustered in a few cities.' ${ }^{3}$ This is significantly divergent from the $10 \%$ estimation given above, thus confirming the existence of conflicting figures on religious affiliation in the DRC. In fact, what comes across in the comparison of figures on religious affiliation is the imprecision of statistics as a majority of Congolese, for instance, are not identified exclusively with any one religious group. Basically, DR Congo's religious configuration exhibits overlapping affiliations, which make exclusive categorisations difficult. In addition, religious identity in DR Congo (as with class and ethnic identities) is often situational and based on pragmatism. ${ }^{4}$

Figures provided by the World Christian Encyclopedia regarding religious affiliation in the DRC prove useful in another regard: they indicate the annual growth rate of each religious group, thus enabling inferences as to the extent of religiosity as well as the attendant influence of religious

2 Although there are conflicting statistics as to religious networks' membership profile in the DRC, these figures have gained wide acceptance in official circles. See About.com. n.d. (a); Answers.com. n.d. and United States Department of State 2004.

3 See About.com. n.d. (b).

4 See About.com. n.d. (b). 
networks in the country. This source indicates that Christians make up over $90 \%$ of the country's population. And the powerful influence of the Catholic Church can be deduced from the figures pertaining to the years 1990-2000 in which its members numbered more than half of the Christian population. Table 1 depicts DR Congo's religious demography:

\section{Table 1:}

Religious adherents in the Democratic Republic of the Congo, 1990-2025

\begin{tabular}{|c|c|c|c|c|c|}
\hline $\begin{array}{l}\text { Religious } \\
\text { cluster }\end{array}$ & $\begin{array}{c}\text { Mid-1990 } \\
\text { Adherents } \\
\quad(\%)\end{array}$ & $\begin{array}{c}\text { Mid-1995 } \\
\text { Adherents } \\
\text { (\%) }\end{array}$ & $\begin{array}{l}\text { Mid-2000 } \\
\text { Adherents } \\
\quad \%)\end{array}$ & $\begin{array}{c}\text { Mid-2025 } \\
\text { (projected) } \\
\text { Adherents } \\
\quad(\%)\end{array}$ & $\begin{array}{c}\text { Percentage } \\
\text { annual } \\
\text { change } \\
(1999- \\
2000)\end{array}$ \\
\hline $\begin{array}{l}\text { Christians } \\
\text { including } \\
\text { Roman }\end{array}$ & $\begin{array}{c}35,392,480 \\
(94.7)\end{array}$ & $\begin{array}{c}43,289,860 \\
(95.3)\end{array}$ & $\begin{array}{c}49,255,901 \\
(95.4)\end{array}$ & $\begin{array}{c}100,935,700 \\
(96.3)\end{array}$ & 3.36 \\
\hline Catholics & $\begin{array}{c}18,750,000 \\
(50.2)\end{array}$ & $\begin{array}{c}23,000,950 \\
(50.6)\end{array}$ & $\begin{array}{c}26,300,000 \\
(50.9)\end{array}$ & $\begin{array}{c}55,000,000 \\
\quad(52.5)\end{array}$ & 3.44 \\
\hline Protestants & $\begin{array}{c}7,780,000 \\
(20.8)\end{array}$ & $\begin{array}{c}9,328,718 \\
(20.5)\end{array}$ & $\begin{array}{c}10,485,000 \\
(20.3)\end{array}$ & $\begin{array}{c}18,862,000 \\
(18.0)\end{array}$ & 3.03 \\
\hline Muslims & $\begin{array}{c}435,000 \\
(1.2)\end{array}$ & $\begin{array}{c}500,000 \\
(1.1)\end{array}$ & $\begin{array}{c}568,656 \\
(1.1)\end{array}$ & $\begin{array}{c}900,000 \\
(0.9)\end{array}$ & 2.72 \\
\hline $\begin{array}{l}\text { Country's } \\
\text { population }\end{array}$ & $37,363,000$ & $45,421,244$ & $51,654,000$ & $104,788,000$ & \\
\hline
\end{tabular}

Source: Barrett, Kurian \& Johnson (2001:211).

It can be seen from Table 1 that Christianity grew at 3.36 percent annually in the DR Congo whilst the annual growth rate for the Catholic Church 


\section{Religious Networks in Post-conflict Democratic Republic of the Congo}

is put at 3.44 percent. ${ }^{5}$ With its extensive membership and the associated influence, the Catholic Church has been described as a 'proto-state' (Callaghy 1984:176). And during the conflict epoch, the Commission for Africa (2005:120) described the Catholic Church as the only reasonable coherent organisation in the country, which functioned as a post office in the absence of a national postal service. Other religious organisations such as the Église du Christ au Congo (ECC) - Church of Christ in the Congo and the Kimbanguist Church also wield tremendous influence in the DRC as a result of their significant memberships, immense resources, and strong external ties. It can be argued that the influence these networks have on the generality of the Congolese may rival (or even surpass) that of the state in view of the enduring state incapacitation arising from years of misrule and protracted conflict. Haynes (1993:116) argues that these religious networks are autonomous structures beyond the state's control and that they provide development goods, which the state has been unable or unwilling to supply to the Congolese. Against this backdrop, it is clear that religious networks are important and powerful actors in DR Congo's public sphere. Their importance as key actors in DR Congo's civil society is also beyond doubt if their roles as social service providers are considered.

It is apposite to mention that religious networks have also facilitated the initiatives that led to the formal cessation of hostilities in the DRC. In particular, the Catholic Church joined forces with other civil society actors to garner support for the Inter-Congolese Dialogue (ICD) which was convened at Sun City, South Africa in April 2003. It was at the ICD that the various belligerents in the DRC conflict signed a cease-fire agreement, which culminated in the formation of a transitional government. It is instructive to note that the Catholic Church sponsored a number of delegates to the ICD,

5 The World Christian Encyclopedia presents what is arguably the most comprehensive information on religious affiliation on country-by-country basis. Hence, it is possible to provide a sketch of religious affiliation in the DRC on the basis of these figures that are widely accepted. However, we hasten to add that a Christian bias is not unlikely in this encyclopedic presentation as population figures do have political and strategic implications in many countries. 
thus underlining its key role in the peace process. ${ }^{6}$ This is one of the several peacebuilding initiatives undertaken by DR Congo's religious networks in the period leading to the formal declaration of the end to the country's conflict. ${ }^{7}$ That said, faith-based actors in the DRC have had to play other crucial roles in the post-conflict epoch. This paper now examines these roles and prognosticates the future of the Congolese state, taking into cognisance the centrality of religious actors to the process of resuscitating the state.

\section{Supporting the democratic transition: religious networks in post-conflict DRC}

...for many years, the Church has had to take the role of the state... [and the performance of that role represents] a moral obligation. ${ }^{8}$

Historically, religious networks had been engaged in public service delivery prior to the eruption of conflict in the DRC. And the onset of war did make religious groups' constructive intervention in public life absolutely imperative. Further, the formal declaration regarding the end of hostilities (or the end of the transition process) did not obviate the need for faith-based social action as the Congolese government is still struggling to establish state authority across the country as at the time of writing this paper (and probably in the foreseeable future). Government's control over Congolese territory has been hampered and continues to be hindered by the military operations and atrocities on the part of the Mayi-Mayi and other militias (notably the group led by 'renegade' General Laurent Nkunda) in the eastern part of DR Congo. However, in recent times, the Kabila administration and MONUC 9 have been making efforts to deal with the security situation in

6 Interview with a Congolese journalist, Kinshasa, 22 Nov 2005.

7 We have examined the salient contributions of the major religious actors to the DRC's peace process elsewhere. For details, see Whetho \& Uzodike, forthcoming (b).

8 Iyananio Molingi of the Diocese of Kasongo, Manirema Province, quoted in IRIN 2006a.

9 MONUC is the French acronym for the United Nations peacekeeping force in the DRC: Mission des Nations Unies en République Démocratique du Congo i.e. United Nations Mission in the Democratic Republic of the Congo. 


\section{Religious Networks in Post-conflict Democratic Republic of the Congo}

the east. Overall, all the provinces of the DRC were made (relatively) safe for the general elections that were held in August 2006 (the first round) and in October 2006 (the second round). Given the relative peace (or the cessation of pervasive hostilities) in DR Congo and the successful conclusion of the elections, the focus of peacebuilding initiatives by religious networks and other civil society organisations shifted (expectedly) to (medium- to long-term) initiatives aimed not only at promoting reconciliation and fostering national unity but also creating the ambience conducive for the reconstruction and resuscitation of state institutions.

The first half of 2006 was marked by an increased national awareness campaign intended to sensitise voters about the 2006 elections. Against the backdrop of an obvious realisation of the powerful influence of religious groups, the Commission Electorale Indépendante (CEI - or the Independent Electoral Commission) co-opted faith-based organisations into its preparations for the elections. The CEI equally carried along other nonreligious civil society actors in the implementation of its mandate. While launching its voter education campaign in April 2006, the CEI distributed sensitisation materials and presented its operational plan for civic action and electoral education to civil society actors including DR Congo's religious organisations. The CEI's operational plan underscored 'the participation of multiple actors in the campaign, including the media, non-state actors, civil society organisations, such as churches, syndicates and other traditional leaders' (Wisniewska/MONUC 2006) in the political process [emphasis added]. Specifically, the CEI trained religious leaders and other civil society actors as part of its capacity-building efforts, which enabled them to promote awareness about the elections.

At another level, the United Nations also held consultations with nonstate actors with a view to promoting their participation in the electoral process. For instance, Jean-Marie Guéhenno, the Under-Secretary General for UN Peacekeeping Operations, visited the DR Congo in March 2006 to consolidate the collaboration between the UN and other stakeholders in the political process. Alwira/MONUC (2006) reported: 'Mr. Guéhenno met Archbishop Laurent Monsengwo, Chairman of the Episcopal Conference in 
the DR Congo to promote civil society involvement in the [2006 general] elections'. On that occasion, Archbishop Monsengwo 'told the media that civil society networks would do all they [could] to discourage and appease those trying to create tension in the democratic process in the DRC' (Alwira/ MONUC 2006). Archbishop Monsengwo's statement lends credence to the capacity of DR Congo's religious groups, as well as other civil society groups, to promote a culture of peace and to mobilise citizens towards massive participation in constructive national processes.

Accordingly, religious groups in DR Congo's post-conflict epoch intensified peace education and electoral sensitisation campaigns within their constituencies and in local communities at large. This initiative was undertaken against the realisation that a peaceful and stable DRC in essence, the country's future - would be determined by the successful conduct of the 2006 general elections and, more importantly, the people's acceptance of the outcomes. ${ }^{10}$ Therefore, the task before religious groups in the aftermath of the elections was to foster reconciliation (first between aggrieved politicians) and to intensify peace advocacy in communities where the recourse to violence was likely due to discontent with the outcomes from the democratic transition process.

However, the success of the elections and post-transition peace was threatened by factors as the resistance to disarmament and demobilisation and, more significantly, the threat of violence by some supporters of defeated presidential candidate, Jean-Pierre Bemba. ${ }^{11}$ The significance of these factors brings the implications of the elections to the fore. Although elections per se do not automatically translate to stability, the successful conclusion of the DRC elections - described as 'the most significant in Africa

10 Interview with JDK, Pietermaritzburg, South Africa, 30 Apr 2006.

11 The results of the second round of the presidential elections, as announced by the CEI on November 15, 2006, showed that Joseph Kabila, the incumbent president, won 58.05 percent of the vote and Jean-Pierre Bemba, the main opposition leader, 41.95 percent. However, Bemba's camp immediately denounced the results, alleging vote rigging by Kabila, thereby heightening fears of possible post-election violence. See British Broadcasting Corporation 2006b. 


\section{Religious Networks in Post-conflict Democratic Republic of the Congo}

since Nelson Mandela was elected as South Africa's president in 1994'12 _ offered Congolese a window of opportunity to build sustainable peace. The elections held the potential to help establish the framework for a legitimate government in which case the (elected) leaders could count on the people's support for reconstruction and rebuilding efforts in the post-transition period. With the benefit of hindsight, the general election was perceived as one that could create the ambience for stability, which the DRC needed (and still needs) in order to put itself on the path to sustainable development. The success of the elections was also crucial for central Africa: a peaceful DRC was (and is) sine qua non for a stable regional neighbourhood. Indeed, a peaceful DRC stood the chance of becoming an economic powerhouse in central Africa and this should give impetus to the process of regional integration and development.

As noted above, harnessing the (potential) positive gains of a successful democratic transition depended on the acceptability of the election results by losers (and their supporters). The fact that some Congolese were disinclined towards a Kabila victory (and consequently, a Kabila presidency) which they viewed as a recipe for chaos, raised serious concerns as to the stability of the DRC. ${ }^{13}$ Given their massive support across the country, ${ }^{14}$ notable political figures opposed to Kabila (Jean-Pierre Bemba and Etienne Tshisekedi being the prominent ones) were seen as key to the success or failure of the transition. It was feared that their supporters might seek to undermine the authority of the government unless these political leaders demonstrated a strong commitment to do otherwise. It was suspected that the DRC might lapse into crisis or slide back into the throes of another war if the frustration arising from electoral defeat was not satisfactorily addressed. In other words, many feared that the contestations of the post-transition

12 See British Broadcasting Corporation 2006b.

13 A cross section of Congolese society has consistently questioned Joseph Kabila's nationality. This group of people has repeatedly alleged that Kabila is not Congolese, that he is a puppet of the international community (read, the West) and that his election to DR Congo's presidency would further divide the country and exacerbate the country's crisis. See British Broadcasting Corporation 2006a.

14 Interview with JDK, Pietermaritzburg, South Africa, 30 Apr 2006. 
epoch might become new sources of tensions that could undermine the success of the elections and consequently threaten the relative but fragile peace and stability that the country enjoyed after the elections. Abbe Paulin Kalala, a Roman Catholic Church priest in Mbuji Mayi, argued poignantly that it was 'possible and even probable that after the elections there [would] be conflict and even war, unless we [entered] into the process of negotiation [to deal with the issues in contention]' (IRIN 2006b). It was also 'feared that the... warlords [might] go back to fighting [in which case the] failure [of the elections would] be so catastrophic, [with the possibility that] the country [might] be divided up like Yugoslavia...' (IRIN 2006b).

In view of the foregoing, religious leaders have had to play a role in 'healing the wounds' of the democratic transition. For instance, faith-based actors were instrumental to reconciling both Kabila and Jean-Pierre Bemba after the latter rejected the election results. Specifically, Catholic bishops brought pressure to bear on both leaders as it urged them to seek a peaceful solution to the electoral crisis by accepting and supporting the mediation process led by the United Nations. ${ }^{15}$

The intervention by religious groups in order to defuse tensions before and after the presidential elections provides a pointer to their continued future engagement and importance in the maintenance of peace in the DRC. In this regard, religious actors' intervention in the crisis in the east becomes imperative. Since the completion of the elections and the inauguration of the new government, DR Congo's religious groups have been emphasising the need for the political class to act responsibly and to put the country first, rather than to allow parochial interests to scuttle the relative peace in the country. ${ }^{16}$ This was not unprecedented, since the Roman Catholic Church had stressed - through its Pastoral Letters - the absolute necessity for politicians to build bridges of understanding as the democratic transition neared its terminal stages. ${ }^{17}$

15 Interview with a Congolese priest, JCA, Durban, South Africa, 5 Dec 2006.

16 Interview with SB, Kinshasa 12 Jun 2007.

17 Interview with a university professor, Lubumbashi, 14 May 2006. 
Apart from the preceding, it is worth noting that Laurent Monsengwo the Archbishop of Kisangani, the president of the Conférence épiscopale nationale $d u$ Congo (CENCO) [the National Episcopal Conference of the Congo] and head of the Roman Catholic Church in the DR Congo - a key political mediator in the country since the time of the late president Mobutu Sese Seko - envisioned a greater role for religious groups in promoting sustainable peace and facilitating the collaborative approach towards handling political differences between politicians in the post-transition epoch. For example, the Roman Catholic Church, in collaboration with other faith-based networks and civil society actors, gave support to the convocation of consultative forums for the reconciliation of political differences and for consensus building which, of course, is germane to creating the conditions necessary for long-term stability and economic prosperity in the DRC. ${ }^{18}$ In the light of the foregoing, Congolese can look forward to increasing civil society engagement (including religious networks' involvement) in DR Congo's public sphere with a view to building on the potential gains of a successful (at least so far and barring a recourse to war) democratic transition. But in view of the crisis in eastern DR Congo, one may conclude reasonably that the prospect for peace in the DRC is either sound or parlous, depending on the commitment of political actors and continuous support from the international community towards addressing the root causes of instability in the country. In fact, it is impossible to conceive of an entirely localised framework for resolving the DRC's problems; the support of the international community is central to the success of the peacebuilding initiatives by governmental and civil society actors.

\section{A case for sustained external support: the international community and the DRC's future}

On the basis of the above, it is worth noting that the international community has been deeply involved and supportive of efforts by the people of the DRC to build peace. Apart from the peacekeeping role of the

18 Interview with a Congolese, Pietermaritzburg, South Africa, 6 Nov 2006. 
United Nations, regional and global actors were also instrumental in giving impetus to the democratic transition. Suffice it to say that the international community's engagement has taken cognisance of the need to collaborate with DR Congo's civil society actors. The United Nations Security Council's 'whirlwind working tour' of the DRC in mid-June 2006 is a case in point. In an apparent recognition of the role of faith-based networks in the (post-conflict) democratic transition process, the UN Security Council delegation's itinerary included 'a meeting with the heads of the various religious organisations in the DRC' which have been recognised as one of the 'many important actors in the Congolese election process' (Young/MONUC 2006). Such engagement by the international community, one which lends critical support to local initiatives, assumes greater significance in view of the massive challenges facing the Congolese state in terms not only of sustaining peace after the elections, but also in regard to reconstruction and the re-assertion of state authority over the entire DR Congo territory. In fact, it would be illogical for the international community to disengage now that the authority of the new government is being constrained by the crisis in the east.

Against this backdrop, the international community has an all-important role to play in building sustainable peace in the DRC. The main role of the international community in the short-, medium- and long-term periods should be to lend critical support to initiatives by the Congolese people to foster reconciliation, rebuild infrastructure and resuscitate state institutions. The United Nations in particular, through MONUC, will have to sustain the process of demobilisation of (ex-)combatants and militias, especially in eastern DRC. The people of DR Congo require sustained, active and even greater engagement by international actors on the long road to recovery and stability. The Congolese government will need the assistance of the international community in resolving the crisis of governance, reviving the health and education systems and creating conditions necessary for investment and for economic growth. It is in these areas that the specialised agencies of the UN will have to play vital roles. In the long term, the international community (in collaboration with local actors) will have to 
assist the Congolese to nurture a culture of (unwavering commitment to) peace. Within this context, one can envision sustained commitment on the part of all actors, including the United Nations and indeed, religious networks, to the peacebuilding process in the DRC.

By and large, DR Congo's religious groups in the post-conflict period have focused on supporting the democratic transition through civic education and advocating responsibility by the political class. The import of their role in the post-conflict epoch had been the nurturing of an environment within which a successful transition could be conducted. This role was underscored by the realisation that the recently concluded elections were crucial to the future stability of the Congolese state. The successful conduct of the elections and the resolution of the post-election crisis engendered optimism regarding a peaceful, stable, and prosperous post-transition chapter in the DRC's history. However, this optimism is being dampened by the instability in the eastern part of the country. Now that the Congolese government is gradually finding its feet, this paper - given its objective - next addresses these questions: What should be the role(s) of DR Congo's faith-based networks in the post-transition epoch and in the not too distant future? Would the cessation of conflict, the successful conduct of elections and the subsequent inauguration of a democratically elected government (buoyed by the people's mandate) obviate the involvement of religious networks in DR Congo's social and political space? The next section ruminates on the roles of religious actors in the post-transition epoch and concludes thereafter with recommendations that should inform not only faith-based peacebuilding but also the involvement of religious actors in the process of state reconstruction. These recommendations draw from the empirical findings (of field research) on religiously motivated peacebuilding in the DRC.

\section{Religious networks and the future of DR Congo}

An accurate prognostication about the future of a phenomenon in the social sciences is very difficult. Expressed differently, it is tricky to predict 
with absolute certainty what future trends or situations will be. This problématique arises, inter alia, from the complexities of social science phenomena, the limitation of human episteme and the fact that events do not necessarily follow linear or unidimensional logic. This prognostic complexity notwithstanding, the predictive facet of social science research remains an important element in empirical scholarly inquiry. As a matter of fact, it is the element of prognostication that often provides the background or justification for further research as it provokes 'new' thinking or the 'other' view, which may lead to the substantiation, or revision, or invalidation of theories, for instance. ${ }^{19}$ However, it is fitting to add that the 'fear' of being confuted has not been and should not be too strong to deter scholars from embarking on prognostic analysis of social science phenomena. Here too, this paper undertakes a futuristic analysis, but of the roles of faith-based actors in the DRC. Suffice it to note that prognostication is often based on the objective interpretation of, and deductions or inferences from, past and current realities. In other words, past and present scenarios tend to define the future, and scholars often draw from these scenarios when making predictions, albeit with due recourse to the ceteris paribus caveat. In line with this 'tradition', this section forecasts the expected roles of religious networks in the post-transition period in the DRC.

The analysis in this section derives from the incontrovertible conception that state deflation or state collapse incapacitates the institutions of governance. Typically, a post-conflict environment creates the necessary imperative to reconstitute the state or rebuild its institutions as the case may be. And the advent of a new administration in the aftermath of a successful post-conflict transition process is more often than not accompanied by multifarious challenges, which the new regime may not be (adequately) equipped to surmount. A new regime may be faced with the tasks of establishing and/ or consolidating its authority, reforming the security sector, building or reconstructing infrastructure, engendering national reconciliation, and

19 Take for example, Samuel Huntington's 'clash of civilizations' prognostic thesis (as it then was), which subsequently engendered a robust scholarly engagement vis-à-vis the main factors that would precipitate conflict in the post-Cold War international system. 


\section{Religious Networks in Post-conflict Democratic Republic of the Congo}

seeking to ensure the provision of basic social services. The enormity of these challenges may even overwhelm the new regime to such an extent that this state of affairs gives civil society actors comparative advantage in the public sphere. Posner (2004:239-240) posits that state collapse (or deflation) undergirds civil society's role in governance in which case non-state actors provide public goods and substitute for a state that cannot yet fully function. In the case of the DRC, the inauguration of Kabila's government has not obviated religious actors' engagement in the delivery of 'public goods'. In fact, insufficient state capacity and government's preoccupation with the insurrection in the east will underpin the continued provision of social services by religious networks, which represent the foremost constituency in DR Congo's civil society.

In conjunction with other non-state actors, faith-based organisations will, for the foreseeable future, play pivotal roles in the public sphere. There is little doubt that the Kabila administration is constrained by challenges to its authority. Within this context, for instance, the reluctance or, more significantly, the resistance to demobilisation and disarmament by some militias, especially in the eastern part of the DRC, presents immediate and future challenges for security sector reform and for DR Congo's longterm stability. It can be reasonably forecast that the Kabila government will continue to be heavily burdened vis-à-vis the containment of violence and the maintenance of security. Civil society actors or (as the case may be) the most powerful non-state actors such as religious networks will then have to continue to perform certain public functions that otherwise should be the preserve of the government.

As the government tries to consolidate its authority and build security (in the eastern part of the DRC in particular), faith-based organisations will continue to find themselves, perhaps, as the only actors that are capable of 
delivering 'public goods.'20 In fact, DR Congo's religious networks have a rich reservoir of history and experience to tap from as far as the performance of social and political roles is concerned. Back in 2006, it was noted that faithbased actors would be involved in the rehabilitation of public infrastructure such as roads, hospitals, and schools in DR Congo's post-transition period. ${ }^{21}$ In addition, the churches, in collaboration with both local and international non-governmental and governmental organisations will have to support an ambitious programme to rehabilitate former combatants (those who have been demobilised or disarmed) in order to prevent their recourse to violence. This role lends credence to the conflict transformational role of religious actors. More than that, the performance of the aforementioned functions by religious and non-religious civil society actors compensates for insufficient state capacity.

Another pointer to the anticipated continued performance of pivotal roles by DR Congo's religious groups in the post-transition period came in March 2006 during the UN Secretary-General Kofi Annan's visit to the country. While in Kinshasa, Annan held talks with a number of stakeholders in the DRC's peace and transition processes, including religious leaders. On that occasion, Laurent Monsengwo, the President of the country's Catholic Bishops' Conference and the Archbishop of Kisangani, presented a request to the UN to the effect that an International Criminal Court (ICC) be set up for the DRC to try perpetrators of war crimes not just for the sake of retributive justice but also to ensure that compensation is paid to victims, 'individual families and the Catholic archdiocese alike'.22 Having made the request for a tribunal for DR Congo, it is anticipated that the country's religious groups will play a prominent role in the processes that would culminate in the prosecution of perpetrators of war crimes and crimes

20 It is however necessary to point out that the extent to which religious networks (and other civil society actors) can function in this regard would depend partly on the level of security or stability in the DRC. There is no gainsaying the fact that non-state actors cannot function effectively where the necessary prerequisites of stability and security are lacking in the polity (Posner 2004: 247).

21 Interview with Pastor JPM, Kinshasa, 30 Mar 2006.

22 See Allafrica.com. n.d. 
against humanity. ${ }^{23}$ One can foresee a role for DRC's religious groups in the process of accounting for the past and forging reconciliation. This brings us to another hoped-for pivotal engagement by DR Congo's religious actors in the post-transition period: serving as catalysts for national reconciliation.

Faith-based actors in the DRC would have to deepen their engagement in the process of national reconciliation. Ex-fighters and even politicians (especially those who might feel aggrieved by the outcome of the last transition process) still need to be reconciled. It is especially important for religious leaders to galvanise public interest in the national reconciliation process. Besides, faith-based actors need to hold consultations with other civil society actors in order to establish the modalities for a post-transition countrywide process of reconciling aggrieved parties. Hence, it is anticipated that in the foreseeable future, religious groups will sustain the national reconciliation process either as its custodians (primarily driving the process) or as facilitators (supporting the government's reconciliation efforts).

There is no doubt that the conflict in the DRC has had a concomitant deleterious effect on not only physical infrastructure but also the country's human resources. So many Congolese, including the country's 'best brains', are outside the borders of the DRC. The new regime will sorely need the best human resources possible in order to deliver 'public goods' and promote sustainable development. Even when some Congolese abroad do return home, the core of the country's public service will consist of those who had remained in the DRC. The Kabila administration will have to work through a civil service that is heavily disoriented, de-motivated and emasculated by autocracy and corruption - some of the infamous legacies of 'Mobutuism'. This poses a serious challenge to the government, and if the new administration were to surmount this hurdle, considerable reform in

23 The ICC has assumed jurisdiction for the crimes perpetrated in the DRC conflict and has issued warrants of arrest in certain cases, the most notable being those for Thomas Lubanga (former leader of the Union of Congolese Patriots militia in Ituri) and Germain Katanga (former leader of the Patriotic Resistance Force in Ituri). Lubanga and Katanga are on trial at the court. 
public service - in terms of orientation and efficient service delivery - will be needed.

It can be safely prognosticated that the success of the regime, say with regard to good governance and social service delivery, will depend to a large extent on individual and institutional capacity building. Here again, civil society, which embraces DRC's religious networks, will play a role in building the capacities of public servants towards promoting good governance and effective social service delivery. The Roman Catholic Church, for example, has demonstrated its ability to lend support to capacity building for good governance in many African countries through its Justice, Development and Peace Commissions. In the DRC, Roman Catholic Church leaders are not oblivious of the need to do the same in the post-transition epoch.24 Its extensive international connections give the Roman Catholic Church considerable leverage to implement capacity-building programmes for political leaders and public servants. The Church could collaborate with both local and international (non-)governmental organisations for the sake of bringing this idea to fruition. Given religious groups' antecedents, therefore, one can expect to see the Roman Catholic Church - just one of the faithbased actors in the DRC - embark on political conscientisation and activism in some way similar to its advocacy in the Mobutu era. Such engagement, it should be noted, would be geared towards ensuring good governance on the part of the new government that derives its mandate from the people.

Against the backdrop of the pivotal place of religious networks in the DRC and their strategic leverage as agents of social mobilisation, it can be said that they are important stakeholders in the project of charting the DRC's future. Although DR Congo's religious groups do not, stricto sensu, measure up to groups that have the means to precipitate violence on a massive scale or the means to subdue it (such as militias, the national army, MONUC), the country's faith-based organisations hold the allegiance of the generality of Congolese given the number of their adherents. Hence, religious networks have the capacity - no matter how minuscule - to either promote stability 


\section{Religious Networks in Post-conflict Democratic Republic of the Congo}

or subvert the peace process and, ultimately, jeopardise the country's future depending on what they 'feed' their members with. Given the socially ambivalent roles that religion plays in public life, religious groups can mobilise their members for both constructive and destructive ends. Therefore, the end to which DR Congo's faith-based organisations mobilise their members will impinge on the country's future. Should religious networks continue with their constructive roles in the post-transition period, they would be contributing to the building of a sustainable climate of peace which, in turn, would guarantee a stable and secure future for the DRC. Suffice it to add that a successful African renaissance agenda needs a DRC that is at peace with itself and its neighbours.

Religious groups have made immense positive contributions to the conflict transformation process and it is inconceivable that they would turn around in the future to undermine their own efforts at building sustainable peace by mobilising their members or deploying their resources for destructive ends. That would be most illogical. In fact, it is only their sustained preoccupation with building sustainable peace that can guarantee their continued existence which, in turn, promotes the realisation of their own objective to 'save souls'. Having said that, this paper next concludes with logical inferences from our field research findings vis-à-vis religious networks' role in the DRC's peace process.

\section{Concluding remarks}

The performance of such roles as facilitating peacebuilding and providing social services by religious actors typifies the constructive element inherent in religion. However, this paper equally acknowledges that religion could be a contrivance for destructiveness, especially when it is used to legitimise or justify violence. Recourse to empiricism in establishing the opposite ends that religion potentially serves illustrates the ambivalence of religion. Hence, it does not come as a surprise that the role of religion in public life is still a contested terrain within the academic community. That said, most scholarly analyses of the nexus between religion and politics present an overarching 
bias, which essentially 'demonises' religion by conceiving it, fundamentally, as a 'hue in the human mosaic' (Jordan \& Rowntree 1990:190) that triggers and exacerbates conflict. The potential and actual (established) constructive roles of religion in conflict situations, more often than not, are marginalised or ignored in scholarly analyses. But the reality of the positive roles of faithbased actors in the peacebuilding processes (including more significantly when and where state actors are not trusted) underscores the need to rethink the role of religion in public life, if only to give expression to its ambivalence. This paper gives cogent representation to the 'other' side of religion that has long been ignored in conflict discourse - the constructive roles of religion as a viaduct for sustainable peace in societies torn apart by the spectre of violence.

In its exploration of the peacebuilding role of religious actors in the DRC, this paper predicates the performance of positive social, economic and political functions by faith-based groups on the notion of liberation theology. Although having eschatological foundations, liberation theology is essentially a social construct that underscores positive collective action towards alleviating pain and suffering. For DR Congo's religious networks, inaction in the face of untold suffering (caused by war) was not only unthinkable but also a sin against the Supreme Being. This paper posits that the involvement of the DRC's faith-based organisations in the public domain (either as agents of development in the pre-war and post-war years or as facilitators of the peacebuilding process during the conflict period) speaks to the intent and spirit of liberation theology. Another underlying causality in the involvement of DR Congo's religious actors in the conflict transformation process is that faith-based networks in the DRC have comparative advantages in the performance of functions that otherwise should constitute the government's core mandate. In a country where state bureaucracy has almost always existed only in name (except for Kinshasa, perhaps), the majority of Congolese have had to rely on non-state actors in the area of provision of social and other crucial life-support services. The onset of conflict in the DRC, this paper contends, deepened the imperative for religiously motivated social action for peace and development. In fact, 


\section{Religious Networks in Post-conflict Democratic Republic of the Congo}

it is apt to recall here that even war-weary Congolese citizens craved for the involvement of faith-based actors in the peacebuilding process. ${ }^{25}$

The peacebuilding initiatives undertaken by DR Congo's religious networks can be suitably situated within the context of conflict transformation. Rather than conducting a manipulative search for an agreement that is acceptable to the warring parties or one that merely satisfies the interests of the parties to the conflict, DRC's religious networks have undertaken roles intended to generate the cumulative effect of shifting the attitudes of parties, transforming structures as well as relationships for durable peace and harmonious coexistence. The country's faith-based actors have been seeking to transform not only the parties' perceptions but also the environment within which the DRC conflict has occurred. Conflict transformation speaks to a long-term commitment to peace. The deconstruction of structures and attitudes that engender violence and the nurturing of 'new' attitudes and modes of organisation, interaction and social cohesion, which promote sustainable peace, exemplify such commitment. Therefore, it is only logical that the involvement of DR Congo's religious networks in the country's public sphere has taken on added significance in the post-conflict period. Since the conclusion of the ICD, religious groups' initiatives have been directed more at the nurturing of a climate that is conducive to sustainable peace. One reality that illustrates the foregoing is their efforts at facilitating the country's democratic transition, promoting national reconciliation and undertaking infrastructural reconstruction. It is this paper's submission that the performance of such roles with the goal of enduring social transformation in mind, and the increasing attention to it in scholarly discourse, should engender a holistic paradigmatic approach to analysing the role of religion in public life.

It is apposite to state at this juncture that the saliency of religious networks' positive roles in the DRC's conflict transformation process is underscored by state deflation/collapse (or what may be referred to as declining statecraft). In fact, the scenario in the DRC exemplifies the increasing socio-political

25 Many of our interviewees stressed this point during field research. 
role of religion within the context of declining statecraft in Africa's conflict zones. It is indisputable that faith-based actors have made (and are making) significant contributions to the peacebuilding and development processes in the DRC. And local and international reactions to religious networks' roles in the public domain have been overwhelmingly positive, albeit a few respondents are cynical of religiously motivated peacebuilding. ${ }^{26}$ Granted, an objective assessment of faith-based actors' involvement in peacebuilding indicates that religious organisations have given momentous impetus to the peace and development processes in the DRC. However, it is noted that some religious institutions target only their members in terms of provision of humanitarian assistance in which case such intervention inadvertently alienates those who profess other faiths - thus deepening divisions in society. Suffice it to add that those who have been marginalised in this regard have been 'compensated' by non-religious civil society actors (whose assistance to war-weary Congolese has not been defined by such factors as creed or religious affiliation), thereby mitigating the frustration and aggression that might have resulted from religiously motivated parochial or partisan assistance.

As a corollary of the foregoing, this paper acknowledges that a number of non-religious civil society actors as well as international donor or humanitarian and governmental agencies have made vital contributions to the process of building peace in the DRC. In some way, the preceding speaks to the complementarity of the peacebuilding efforts by DR Congo's religious networks and local or international non-religious civil society actors. However, this paper has focused primarily on the roles of faith-based actors in the DRC's conflict transformation process and the ramifications of their involvement for the DRC's future. In tackling its essential concern as described above, the paper recognises that faith-based peacebuilding in the DRC has not been without its drawbacks and, therefore, concludes with recommendations that should underpin religiously motivated efforts at building sustainable peace in societies torn apart by conflict.

26 For a comprehensive account of the diverse reactions to the involvement of faith-based actors in the DRC conflict, see Whetho \& Uzodike, forthcoming (a). 


\section{Religious Networks in Post-conflict Democratic Republic of the Congo}

The first recommendation is derived from a significant drawback in faithbased peacebuilding. As noted above, some of DR Congo's religious networks have embarked on peacebuilding initiatives that can be described as partisan in that their programmes do not address the needs of the wider society but those of their members only. The implication of this is the alienation of those excluded in the communities in which case the actions of religious networks, albeit potentially, inadvertently engender divisions and ultimately conflict. In such instance, faith-based actors might contribute to the intensification of factors that precipitate conflict rather than create the conditions for unity or social cohesion and peace. Having said that, one has to acknowledge that religious organisations have a primary obligation to undertake programmes that target their followers at particular times. But given the inadvertent consequences of partisan faith-based social engagement, this paper recommends that religious networks focus on high profile projects that show them as having the capacity and interest to look beyond denominations and religion. For a certainty, the implementation of high profile non-partisan conflict transformation initiatives by DR Congo's religious networks will contribute to fostering reconciliation and social cohesion.

Research findings suggest that many of DR Congo's religious actors, especially religious leaders, have been implementing peacebuilding initiatives in their personal capacities. Besides, their performance of peacebuilding functions has been predicated on the 'social mission' drawn from religious convictions rather than on professionally enabled or enhanced personal capacities. In other words, religious groups and actors do not always possess the professionalism required in conflict transformation processes. Hence, there is the need to build the capacities of DRC's religious actors to complement the theological underpinnings of faith-based conflict transformation work. In so doing, faith-based actors can anticipate the replication of successes attained by other (professionally) trained civil society actors involved in peacebuilding.

A corollary of the foregoing is the need to separate religiously motivated social action (in this case peacebuilding) from a purely religious mission such as proselytising. Some Congolese are critical of faith-based organisations' 
involvement in public life as churches often provide social services in order to induce conversion. In fact, some respondents during field research were unreservedly cynical of (the motivations for) faith-based peacebuilding. Although the underlying basis for faith-based social action is religious (as it derives from liberation theology), the goal of such involvement should not be to promote the conversion of persons but rather to complement the efforts of local and international (non-)governmental agencies in alleviating the effects of political instability.

Research findings indicate that DR Congo's religious groups have broadened their peacebuilding initiatives to embrace several processes in the conflict transformation spectrum. For instance, it is not uncommon to find that a faith-based organisation is involved in several processes (such as peace advocacy; humanitarian or relief services; negotiation, mediation or reconciliation; demobilisation or reintegration of ex-combatants; and reconstruction) at the same time. In such instances, their efforts are dispersed and do not yield homogeneous results. Therefore, it is necessary that religious groups identify areas of comparative advantage and competence in the peacebuilding spectrum. This will make for thorough involvement and deeper engagement in which case the benefits of intervention can be harnessed and enjoyed more fully. For now though, it can be safely prognosticated that religious networks will be more inclined towards making decisive positive contributions to the social, economic and political development of the DRC.

\section{Sources}

About.com. n.d. (a). Congo, Democratic Republic of the: Country Facts, <http://atheism. about.com/library/world/KZ/bl_ZaireFacts.htm> Accessed 7 Jul 2005.

About.com. n.d. (b). Religion in Zaire: Religion Index, <http://atheism.about.com/library/ world/KZ/bl_ZaireIndex.htm> Accessed 7 Jul 2005.

Allafrica.com. n.d. Congo-Kinshasa: Catholic Bishops Ask for UN Criminal Court for Congo, $<$ http://allafrica.com/stories/200603310349.html> Accessed 4 Apr 2006.

Alwira, W.E./MONUC 2006. Abstain from using youth gangs, Guéhenno and Archbishop urge politicians, <http://www.monuc.org/News.aspx?newsID=10262> Accessed 13 Mar 2006. 


\section{Religious Networks in Post-conflict Democratic Republic of the Congo}

Answers.com. n.d. Demographics, <http://www.answers.com/topic/congo-country-zaire> Accessed 7 Jul 2005.

Barrett, D., Kurian, G. \& Johnson, T. (eds) 2001. World Christian Encyclopedia (2nd edition). New York: Oxford University Press.

Berger, P.L. 1999. The desecularization of the world: Resurgent religion and world politics. Grand Rapids: Eerdmans.

British Broadcasting Corporation 2006a. DR Congo elections: Your views, 28 Oct 2006. <http:// newsforums.bbc.co.uk> Accessed 30 Oct 2006.

British Broadcasting Corporation 2006b. Kabila calls for calm in DR Congo, 16 Nov 2006. $<$ http://news.bbc.co.uk/2/hi/africa/6153184.stm> Accessed 16 Nov 2006.

Bunting, M. 2005. Where Faith is a Healer. The Guardian (UK), 28 Mar 2005.

Callaghy, T.M. 1984. The State-Society Struggle: Zaire in Comparative Perspective. New York: Columbia University Press.

Commission for Africa 2005. Our Common Interest: Report of the Commission for Africa. London: Penguin Press.

Cox, H. 1965. The Secular City. New York: Macmillan.

Crawford, R. 2002. What is Religion? London \& New York: Routledge.

Haynes, J. 1993. Religion in Third World Politics. Buckingham: Open University Press.

Jordan, T.G. \& Rowntree, L. 1990. The Human Mosaic: A Thematic Introduction to Cultural Geography. New York: Harper \& Row.

Lubbe, G.J.A. 2002. Religious nationalism confronting the secular state, in Du Toit, C.W. \& Lubbe, G.J.A. (eds), After September 11: Globalisation, War and Peace. University of South Africa: Research Institute for Theology.

Posner, D.N. 2004. Civil Society and the Reconstruction of Failed States, in Rotberg, R.I. (ed), When States Fail: Causes and Consequences. Princeton: Princeton University Press.

Reychler, L. 1997. Religion and Conflict. The International Journal of Peace Studies 2 (1).

Rubin, B. 1994. Religion and International Affairs, in Johnston, D. \& Sampson, C. (eds), Religion, the Missing Dimension of Statecraft. New York: Oxford University Press.

Thomas, S.M. 2000. Taking religion and cultural pluralism seriously: The global resurgence of religion and the transformation of international society, Millennium: Journal of International Studies 29 (3).

United States Department of State 2004. 'Congo, Democratic Republic of the: International Religious Freedom Report 2004’, 15 Sep 2004. <http://www.state.gov/g/drl/rls/ irf/2004/35348.htm> Accessed 12 Dec 2005.

Wallace, A. 1966. Religion: Anthropological View. New York: Random.

Weigel, G. 1991. Religion and Peace: An argument complexified. The Washington Quarterly, Spring. 
Whetho, A. \& U.O. Uzodike, forthcoming (a). Assessing the role of religious networks in the peace process: Views from the Democratic Republic of the Congo.

Whetho, A. \& U.O. Uzodike, forthcoming (b). Religious networks in conflict and peace: The case of the Democratic Republic of the Congo, 1996-2006.

Wilson, B. 1982. Religion in Sociological Perspective. Oxford: Oxford University Press.

Wisniewska, M./MONUC 2006. 'IEC launches national campaign for voter sensitization', $<$ http://www.monuc.org/News.aspx?newsID=10698> Accessed 19 Apr 2006.

Young, E./MONUC 2006. 'UN Security Council to conduct whirlwind working tour to DRC', $<$ http://www.monuc.org/News.aspx?newsID=11314> Accessed 9 Jun 2006.

\section{Anonymous interviews}

Interview with Pastor JPM, Kinshasa, 30 Mar 2006.

Interview with Reverend Father FGM, Katanga, 18 Nov 2005.

Interview with JDK, Pietermaritzburg, South Africa, 30 Apr 2006.

Interview with a university professor, Lubumbashi, 14 May 2006.

Interview with a Congolese, Pietermaritzburg, South Africa, 6 Jun 2006.

Interview with a Congolese priest, JCA, Durban, South Africa, 5 Dec 2006.

Interview with SB, Kinshasa 12 Jun 2007.

\section{Personal correspondences}

IRIN (Integrated Regional Information Networks) 2006a. Civic education crucial ahead of poll, official says, E-mail from IRIN News, 29 Mar 2006.

IRIN 2006b. To vote, or not to vote, E-mail from IRIN News, 8 Jun 2006. 